\title{
A Study on Employment for Rural Laborers in the Process of Industrialization and Modernization of Vietnam
}

\author{
Van Hieu Pham, Van Hoa Vu, Van Dang Pham \\ Hanoi University of Business and Technology, Vietnam \\ Manh Dung Tran, Mai Van Trinh \\ National Economics University, Vietnam
}

\begin{abstract}
Employment and job creation are global socio-economic issues and concern every country in the world and Vietnam is no exception. Today, the concept of development is comprehensively understood and economic growth is associated with progress, social justice, poverty reduction, on the basis of creating sustainable jobs for workers. At different times, employments for workers also have different characteristics. In the dimension of this study, employment for rural laborers with the case study of Nam Dinh of Vietnam have been investigated, then some recommendations are proposed for creating more jobs for rural people.
\end{abstract}

Keywords: Employment, job creation, rural employment, rural labor.

DOI: $10.7176 / \mathrm{EJBM} / 12-21-13$

Publication date:July $31^{\text {st }} 2020$

\section{Introduction}

In Vietnam, labor in agriculture and rural areas currently accounts for $67.4 \%$ of the national labor force, but only $14.4 \%$ of these workers have obtained the technical and professional qualifications (technical / professional qualifications); The number of poor people in rural areas accounts for more than $90 \%$ of the total number of poor people throughout the country, the percentage of free time of rural labor accounts for about $30 \%$ (data of 2018).It is worth mentioning that the quality of employment in this area is very low and little improved after the Employment Strategy of 15 years ago (2001-2010 and 2011-2015). Currently, the national simple and unskilled jobs account for nearly $40 \%$ of the total employments in the country, this rate is $18.1 \%$ in urban areas, but this proportion in rural areas accounts for nearly $50 \%$ of the total employments.

Nam Dinh, a province in the Red River Delta (RRD), has a population of nearly 2 million people with abundant labor resources. It is also one of the localities which has a high unemployment rate in rural areas. In recent years, although the province has made great efforts to promote the development of rural economy and create jobs for workers, the shortage of jobs in this area has been increasingly serious, and many workers have to suffer from labor shortage. They have left their native home for work in other localities. This is really a difficult problem for Nam Dinh at present, which shows that the "bottlenecks" in the local socio-economic development need to be removed. Therefore, the proper assessment of employment status in rural areas, the placement of rural employment in the context of the development of a market economy, international economic integration (ICD) and the development of the intellectual economy to reveal the shortcomings, causes and barriers in rural labor employment will help the locality see clearly the inadequacies in agricultural and rural development as well as the whole economy of the province; On that basis, there have been effective measures to promote rural economy development. At the same time, the development of sustainable agriculture, a diversified market- oriented rural economy and international economic integration will create many job opportunities, increase income for rural workers, accelerate the process of agricultural and rural industrialization, modernization of the localities Moreover, the typical case study of Nam Dinh province will also give valuable experience to solve employment problems in the different rural localities of Vietnam.

\section{Literature review}

It is worth noting that some development theories discuss the ways or economic development models of LDCs in the process of industrialization. These theories have considered the use of resources for economic growth at different stages in the industrialization process and discussed the most basic content of industrialization which restructures the economic sectors.

The important theories about employment such as Keynesian theory, Toshima's theory, Harris - Todaro's employment model studied job issues from different perspectives. In Keynesian theory, employment is considered in relation to the aggregate demand of the national economy. Toshima again studied the basic characteristics of the monsoon Asian economy with the goal of changing the economy from the inadequate use of labor to full employment of workers through three stages of development of the economy. Todaro also studied employment in developing countries by moving labor based on the implementation of income and salary regulation among different economic sectors. The above theories have shown that the jobs created depend on the increase in output 
and the mode of growth of an economy; contribute to the explanation of unemployment and underemployment as well as mass migration from rural to urban areas in developing countries in the industrialization; At the same time, it also points out the development steps towards full employment of developing economies. However, these theories have not clarified the role of the Government through a system of economic policies combined with social policies to create stable jobs for the economy.

A number of researches on labor market such as Fine (1998), analyzed the theoretical issues on the labor market from the concept, nature and components of the labor market to labor market evaluation indicators. While other studies looked at labor market in specific countries, such as those by Lu et al. (2008), analyzed the impact of reform of labor market on productivity, wages and employment issues in 2 periods: 1978-1996 and from 1996 onwards in China.

Foreign scholars' studies on employment in Vietnam such as Jenkins (2004), has showed that although Vietnam has achieved economic growth, hunger elimination, poverty reduction, opening up and integration to accelerate development in the 1990s, job development results were not as expected. The study also pointed out that the employment growth rate in the foreign invested sector is much smaller than the growth rate of output. The underlying reason is that the region often focuses on capital-intensive industries. Thus, it is difficult to rely on the FDI sector in job development when the added value (AV) - the basis for developing the quality jobs created by them is too low.

The research of Cling et al. (2009) and Jenkins (2004) focused on the quality of employment of Vietnam in the growth model under export-led growth, especially in the region with foreign-invested capital. Studies have shown that some of Vietnam's export-oriented industries have made technological and human advances to create higher value-added products and limit competition from other underdeveloped countries. However, this pace of progress is too slow, greatly affecting the development of quality jobs in Vietnam in export-oriented industries in particular and the whole economy in general.

In addition, a number of studies by international authors and organizations have discussed Vietnam's labor, employment and job creation, and recommended and proposed consultation policies for the Vietnamese Government in the field of employment. Typical is the UNDP Labor and Employment Approach Report (2010) which analyzes the importance of labor market development; problems with growth, wages and migration. On the basis of comparative analysis of some development models of East Asian and Southeast Asian countries (NICs group: Singapore, Hong Kong, Taiwan, South Korea; group of Southeast Asian countries: Malaysia, Indonesia, Thailand; and China, India) on growth and employment strategies, labor market policies and institutions. Or ILO Report (2014) emphasizes the importance of coordinating an effectively designed social protection system with a strategy to increase labor productivity in agriculture, at the same time, creating a favorable environment for attracting and expanding the development of enterprises in the formal sector of the economy. World Bank Report on Vietnam Development in 2014 which says Skill development: Building a workforce for a modern market economy in Vietnam shows that Vietnam needs to equip new skills for its labor force so as to continue the process of economic modernization and proposed 3 skill groups, which are behavioral skills, cognitive skills and technical skills. At the same time, the report also provides recommendations for skill development in Vietnam.

In the context of Vietnam, directly related to jobs in rural areas are typical projects including Le (2008); Hanoi University of Agriculture (2012); Bui (2007); Tran (2010); Chu (2001), Chu (2005) which all mentioned some theoretical issues and practical experience on employment and job creation for rural workers in the process of industrialization, urbanization and integration, pointing out resources for rural development. ; analyzed the real situation of rural employment in general and the Red River Delta region in particular, proposing practical orientations and solutions in order to create jobs for agricultural and rural workers in the process of industrialization, modernization and urbanization.

Regarding the development of the labor market, employment creation and allocation and use of human resources are typically the studies of the scientists such as Nguyen (2002), Pham (2003), Nguyen (2004), Nguyen (2005), Nguyen (2011), Tran (2011) and others. These studies have considered theoretically the nature of the labor market and its components; analyzed the current situation of labor supply and demand of Vietnam in recent years; assessed the indicators of employment, unemployment, wages and labor migration... pointed out the shortcomings of Vietnam's labor market at points such as: large imbalance between labor supply and demand; low level of "marketization" of labor relations; inadequate wage policy (price, labor); system of labor market tools did not meet the requirements; State management of the labor market still had many weaknesses... On that basis, the solutions to promote labor market development in order to meet the requirements of economic restructuring and international economic integration is proposed.

A number of researches on the use and displacement of agricultural and rural labor sources are by such typical authors as Tran (2001), Ngo (2012). These works clearly state the characteristics of agricultural and rural labor; factors affecting the quantity and quality of rural labor force, affecting the use of this labor force; study of rural labor mobility with impact factors; experience using agricultural and rural labor force in some countries and territories. From the current situation of shifting and using the rural labor force, the solutions to effectively use the 
rural human resources in the process of industrialization and modernization have been proposed.

In this study, the employment and job creation for rural workers are considered in the context of new development, which is the developing world economy with two major prevailing trends that are globalization and development of intellectual economy. After these two trends, the world economy is changing deeply and comprehensively in terms of technology level, product structure and economic institutions, creating a transition to a new era of human economic development. The new economic era has the following basic characteristics: (i) modern market economy system, macro and mixed market economy; (ii) the scientific and technological revolution (S\&T) with the structure in which the intellectual economy is the foundation; (iii) global economy. With these characteristics, modern development is a fundamental change in the mode of production, in the economic structure, therefore, a fundamental change in the capacity and productivity of mankind. Modern development has led to a complete change of the old development model by: (i) breaking the self-contained, selfreproducing structure of the classical development model. Globalization has created a new structure for the development process - the global economic network structure based on the global social division of labor system, in which national economies are restructured into links to global production and service network. The principle that governs this labor division system is the global "supply chain" or "added value chain" principle; (ii) change factors in production function, of which the knowledge and modern technology are the decisive factors, at the same time, they are also the factors that make up a common condition of development and play the dominant role; (iii) The State as the owner of the development of a nation is a specific factor of modern development. Thus, the modern market economy system; Knowledge economy and globalization are new factors that have a decisive impact on the economic restructuring, employment structure and development of each nation.

Thus, in the context of industrialization and international integration, facing the requirements of applying modern science and technology and improving labor productivity, employments in rural areas also change towards improving the quality and value-added content. Current rural employment must be linked to a modern agriculture towards improving the quality of agricultural commodities on the domestic and international markets; at the same time, it is necessary to improve the quality of production processes in each agricultural sub-sector, as well as improve the content of added value (AV) of each product and each stage in agricultural production activities.

\section{Research methodology}

Collecting and processing information: Documents and secondary data sources related to the research issue are collected and some previous research results, in order to clarify the theoretical and practical issues of the research problem are inherited.

- Statistical method: Secondary statistics used in the study are collected from the relevant data sets of General Statistics Office, Nam Dinh Statistical Office, Ministry of Labor - Invalids and Social Affairs. Association, Department of Labor - Invalids and Social Affairs of Nam Dinh, Department of Agriculture and Rural Development of Nam Dinh, Management Board of Provincial Industrial Zones, reports, schemes, socio-economic development plans of localities.

- Method of systematic analysis: This method is used to analyze actual data on socio-economic development results, job creation results in relation to other resources for agriculture and rural economy development in Nam Dinh province.

- Comparison method: This method is used in analyzing the situation of job creation in rural areas in Nam Dinh province to identify the trend, level of variation and displacement of rural labor.

- Methods of survey and investigation: In order to understand more deeply the situation of employment fluctuations of rural workers in Nam Dinh province in the past time, we have chosen two points to survey, which is My Tan commune (My Loc district) and Truc Phu commune (Truc Ninh district). These are two communes in two agricultural areas of Nam Dinh.

We used the questionnaire to survey 200 households in the 2 communes mentioned. There are 194 valid votes. The content of the questionnaire focused on clarifying the following issues: General information about the household (demographic, labor, household ranking according to rich and poor criteria, land situation and economic development of the household); educational and technical qualifications of household members; their employment status as well as their occupation; fluctuations of workers in the process of implementation of urbanization and industrialization; possibility of rural labor participation in the labor market. Data and information are surveyed, collected and processed mainly by statistical methods and via excel tables.

- Method of experts: We consult experts in the field of labor - employment; key local officials in departments and agencies: Department of Planning and Investment, Department of Labor, War Invalids and Social Affairs, Department of Agriculture and Rural Development; Industrial Zones Management Board, Farmer's Union to understand the situation and the cause of the existence in creating jobs for rural workers in Nam Dinh province. 


\section{Results and discussion}

4.1. Implementation of industrialization, modernization and policies and programs to create jobs for workers in Nam Dinh province

Along with the whole country, Nam Dinh has implemented the Provincial Human Resource Development Plan for the period of 2011-2020, with the orientation of reducing vocational training that has saturated social needs, linking training plans with business needs. Training skilled human resources have been effectively realized to meet the needs of new rural development, job creation and labor export.

In the Prime Minister's Decision No. 1956/QD-TTg of November 27, 2009, approving the Project "Vocational training for rural laborers up to 2020", on June 24, 2010, Nam Dinh Provincial People's Committee issued Decision No. 1220/2010/QD-UBND approving the "Project on vocational training for rural workers by 2020", aiming to improve the quality of human resources, create stable jobs and increase the income of rural labor, contributing to labor and economic restructuring, meeting the requirements of rural agriculture industry. Based on this project, each year, vocational training would provide for about 31 thousand workers (of which 25 thousand are rural workers); the proportion of trained workers with jobs was about $95 \%$ and the rate of employed laborers who were suitable to the trained occupations was $85 \%$; By 2015, the percentage of trained workers would reach $42 \%$ and $60 \%$ by 2020 .

In the period of 2010-2018, the whole province organized nearly 900 vocational training classes for 24,477 rural laborers (labor force learning agricultural jobs was 6,412 people, accounting for $26.2 \%$; labors studying nonagricultural jobs was 18,016 people, accounting for $73.8 \%$ ), over $85 \%$ of trained workers got jobs with an average stable income of 3-5 million a person per month. The apprentices have got basic knowledge of vocational skills and are able to work in enterprises or to create jobs for themselves. In particular, agricultural apprentices organize more efficient production, especially on farm and farm owners. 18,919 people were supported with vocational training with a total budget of VND 38.57 billion. The main training occupations were: breeding, aquaculture, mushroom production and processing, cultivation, and industrial sewing.

In the field of agriculture, Nam Dinh is speeding up the implementation of the Prime Minister's Decision No. 62/2013 / QD-TTg of October 25, 2013, on the policies to encourage development of cooperation and production links associated with consumption of agricultural products, construction of a large sample field in order to develop market-orientedagriculture and improve agricultural labor productivity; at the same time, building a scheme on agricultural restructuring in Nam Dinh province to develop efficient and sustainable agriculture.

It can be seen that the guidelines and policies of the State to promote the development of rural agriculture in recent years have been right and in line with the development requirements in the new period. However, a number of laws and sub-law documents of the State are not synchronized and strong enough to create motivation for agricultural and rural development on which basis the employment problems for rural workers in general and in Nam Dinh in particular will actively be solved. The guidance of central government, the ministries and branches has not yet been timely followed by the law and the content is inconsistent with the reality. For example, the Land Law and a number of guiding documents have not encouraged the accumulation and concentration of land. The duration of agricultural land use is always the content that makes many farmers anxious when the expiry of the agricultural land allocation period comes (2013) The State will proceed to redistribute the entire land. This psychology has greatly affected the issue of investment in production development and land consolidation in farmers. Besides, there have also remained unresolved obstacles in the implementation of site clearance and land acquisition when implementing the Land Law.

On the local side, there has been a lack of uniformity in the organization of the planning, for example, the agricultural production planning and the new rural planning to be instructed for implementation have been completed before the Government assigns land quotas, planting rice for the province and land use planning of 3 levels (province, district and commune) have not been approved. Therefore, land consolidation in the province has encountered many difficulties because it has to ensure compatibility between agricultural production plans, NTM construction and land use plans.

There are still some problems in organizing the implementation of local policies, such as vocational training policies for rural laborers, although achieving the goals in terms of quantity, but the quality of training is not high due to the local conducted a survey of farmers' training needs in order to create favorable conditions for rural vocational training to be suitable with their educational levels, economic conditions and vocational training needs. Nam Dinh needs to link vocational training with local socio-economic development strategies, planning and plans.

\subsection{Employment restructuring by economic sectors in rural areas of Nam Dinh}

In fact, economic growth is always associated with growth and employment mobility across economic sectors, which is reflected in the data in Table 1. 
Table 1: Employment and employment structure of Nam Dinh province by sectors

\begin{tabular}{|l|c|c|c|c|c|}
\hline \multicolumn{1}{|c|}{ Year } & $\mathbf{2 0 1 0}$ & $\mathbf{2 0 1 5}$ & $\mathbf{2 0 1 6}$ & $\mathbf{2 0 1 7}$ & $\mathbf{2 0 1 8}$ \\
\hline \multicolumn{1}{|c|}{ Total (persons) } & $\mathbf{1 , 0 4 0 , 6 9 3}$ & $\mathbf{1 , 0 6 6 , 7 5 2}$ & $\mathbf{1 , 0 7 9 , 1 3 8}$ & $\mathbf{1 , 1 0 6 , 9 5 1}$ & $\mathbf{1 , 1 3 5 , 1 7 8}$ \\
\hline 1. Agriculture, forestry \& fishery & 716,224 & 644,665 & 633,061 & 621,656 & 610,476 \\
\hline 2. Industry and construction & 146,419 & 221,174 & 227,809 & 244,643 & 258,982 \\
\hline 3. Services & 133,629 & 200,913 & 218,271 & 240,652 & 265,720 \\
\hline \multicolumn{7}{|c|}{ Structure (\%) } \\
\hline 1. Agriculture, forestry \& fishery & 71.9 & 60.4 & 58.7 & 56.2 & 53.8 \\
\hline 2. Industry and construction & 14.7 & 20.7 & 21.1 & 22.1 & 22.8 \\
\hline 3. Services & 13.4 & 18.9 & 20.2 & 21.7 & 23.4 \\
\hline
\end{tabular}

Source: Nam Dinh Statistical Yearbook (2019) and authors' calculations

In the period of 2010-2018, the fluctuation of employment in Nam Dinh was shown: the whole economy increased by 94,485 jobs, of which the agriculture, forestry and fishery sector decreased by 105,748 jobs, corresponding to the employment rate, decreased $-18.1 \%$, but still high compared to the national average (in 2018, the employment rate in this sector of the country was $37.7 \%$, Nam Dinh was $53.8 \%$ ). The service sector saw the largest increase in employment: 132,091 jobs in the same period, due to the increase in new jobs and the partial employment of agriculture; industry and construction increased slowly, increasing 112,563 jobs.

The fact also shows that there is a mismatch between the transformation of GDP structure and employment structure by economic sectors of Nam Dinh. Until 2018, the province's agricultural, forestry and fishery structure accounted for more than half of the total employment (53.8\%), while the value of agricultural production accounted for just over 1/5 (20.63\%) of the provincial GDP. This shows that most of Nam Dinh's jobs are concentrated in agriculture, essentially the "stagnation" of labor in rural agriculture. The service sector has experienced the most employment growth in recent years, but the production value of the service sector is only equivalent to the GDP of the industry (38.2\% and $38.07 \%$, respectively). It shows that employment in the service sector is still in low quality and low productivity.

The survey data in 2 communes Truc Phu and My Tan with a total of 194 households and 453 employees also shows that the percentage of agricultural jobs cum other occupations accounts for the majority, 67.41\% (Truc Phu commune and 62\% (My Tan commune), although My Tan is one of the communes with the number of laborers working with many non-agricultural occupations.

Table 2: Survey data on job type of 2 communes of Truc Phu and My Tan

\begin{tabular}{|l|c|c|}
\hline \multicolumn{1}{|c|}{ Targets } & Truc Phu & My Tan \\
\hline Number of employees (people) & $\mathbf{2 2 4}$ & $\mathbf{2 2 9}$ \\
\hline Agricultural labor & 116 & 98 \\
\hline Industrial labor & 33 & 41 \\
\hline Service labor & 40 & 46 \\
\hline Agricultural workers \& other industries & 35 & 44 \\
\hline Ratio (\%) & & 42.79 \\
\hline Agricultural labor & 51.79 & 17.91 \\
\hline Industrial labor & 14.73 & 20.09 \\
\hline Service labor & 17.86 & 19.21 \\
\hline Agricultural workers \& other industries & 15.62 & \\
\hline
\end{tabular}

Source: Survey data of the authors

In Nam Dinh, the agriculture which is the main economic sector of the province is being developed based on the elderly labor force, because one part of young workers is participating in different industrial zones; another part has moved to the key economic regions of the Southern provinces or provinces of Bac Ninh, Vinh Phuc to work. Moreover, female workers working in industrial zones after the age of 35 must return to the fields because businesses always recruit young workers to suit working conditions in the garment and electronic industries... This is really a difficult problem to create jobs for local workers, especially the female labor force aged 40 and over.

\subsection{Employment shift by economic sector}

It can be seen that in Nam Dinh, the majority of employees working in non-state economic sectors account for overwhelming proportions in both absolute and relative numbers. In the period 2010-2018, the employment rate in the State sector accounted for more than 5\%, in the non-State sector, the number fluctuated between $90-93 \%$; employment rate in the FDI sector was still low, but tended to increase from $1.44 \%$ in 2010 to $5.16 \%$ in 2018 . 
Table 3: Employment in Nam Dinh by economic sectors period 2010-2018 (\%)

\begin{tabular}{|l|c|c|c|}
\hline & $\mathbf{2 0 1 0}$ & $\mathbf{2 0 1 5}$ & $\mathbf{2 0 1 8}$ \\
\hline State economy & 5.59 & 5.50 & 5.14 \\
\hline Non-state economy & 93.18 & 91.45 & 89.70 \\
\hline Foreign-invested sector & 1.44 & 3.05 & 5.15 \\
\hline
\end{tabular}

Source: Nam Dinh Statistical Yearbook (2018)

In rural areas, household economy is still the main form of production organization in Nam Dinh and is the type of production that attracts the majority of the rural labor force of the province with nearly 270,000 households. On the first of January in 2018, there were 365 cooperatives in the whole province, reducing 2 cooperatives in comparison with 2017 including 275 agriculture, forestry and fishery cooperatives, accounting for $75.34 \% ; 29$ industrial and construction cooperatives, accounting for $7.95 \%$; 61 service cooperatives, accounting for $16.71 \%$. The number of employees in the cooperatives consists of 6,421 people, the decrease of 560 people compared to the previous year, of which 4,848 workers are engaged in agriculture, forestry and fishery, accounting for $75.50 \%$; 487 industrial and construction workers, accounting for $7.59 \% ; 1,086$ service workers, accounting for $16.91 \%$.

In 2018, the whole province had 104,435 individual non-agricultural, forestry and fishery economic establishments, increased by $1.6 \%$ compared to the previous year; in which industry with 32,934 establishments, accounting for $31.6 \%$; construction 3,431 establishments, accounting for 3.3\%; transport, warehousing 6,194 establishments, accounting for 5.9\%; 44,104 commercial establishments, accounting for $42.2 \%$ and the service with 17,790 establishments, accounting for $17 \%$. The total number of employees participating in non-agricultural individual economic establishments was 208,452 people, an increase of $4.9 \%(+9,696$ employees) from the previous year.

So, in terms of assessing the resources of land, human resources, capital, science and technology with job creation for rural workers in Nam Dinh province, there is a great imbalance between limited resources (land, capital, science and technology) and a huge demand for employment for rural workers in Nam Dinh. In recent years, the province's agricultural sector has mainly developed in width: expanding aquaculture area, diversifying a number of crops and livestock (expanding potato, clean vegetables and trees), landscape, increasing the number of pigs and poultry...), at the same time, applying technical and scientific advances in a number of stages: soil preparation, harvesting, use of new rice varieties, potatoes...

In fact, intensive farming methods to increase crop and livestock productivity in the local agriculture seem to achieve little effect. In order to develop agriculture in the direction of increasing added value and sustainability, we need to change the mode of growth in depth. This is one of the very important issues to be solved in the near future.

4.4. Developing non-agricultural jobs in rural areas

- Changes in employment structure in rural areas following the trend of job transfer from agricultural to nonagricultural sectors

Table 4: Pure agricultural labor and agricultural work with other occupations (persons)

\begin{tabular}{|c|c|c|c|c|}
\hline \multirow{2}{*}{ Year } & \multirow{2}{*}{2011} & \multirow{2}{*}{2016} & \multicolumn{2}{|c|}{ Changes } \\
\hline & & & Absolute & ratio $(\%)$ \\
\hline Total & $\mathbf{5 8 2 , 3 7 7}$ & 381,756 & $-200,621$ & -34.45 \\
\hline - Pure agricultural labor & 444,075 & 231,455 & $-212,620$ & -47.88 \\
\hline -Agricultural labor cum other occupation, including: & 138,302 & 150,301 & 11,999 & 8.68 \\
\hline+ cum forestry, fishery & 14,626 & 21,967 & 7,341 & 50.19 \\
\hline+ cum industry-construction and services & 123,677 & 128,334 & 4,657 & 3.77 \\
\hline
\end{tabular}

Source: Results of the rural, agriculture and fishery census Nam Dinh $(2011,2016)$

From 2011 to 2016, the number of agricultural jobs of Nam Dinh decreased by 200,621 (- 34.45\% compared to 2011). Notable points of the decline in agricultural employment of Nam Dinh lie in the fact that during this period, the number of purely agricultural workers decreased most $(-212,620$ people, with $-47.88 \%)$, while the number of agricultural jobs and other occupations increased by 11,999 (equivalent to 8.68\%).Of the 11,999 agricultural jobs cum other occupations increased during 2011-2016, there were 7,341 agricultural jobs cum forestry and fishery (accounting for 50.19\%), there were only 3.77\% agricultural jobs cum more industry construction and service occupations. This shows that the employment restructuring of rural areas in Nam Dinh mainly takes place within the agriculture, forestry and fishery sectors; job creation in rural industry and service sectors is still very limited. 
Table 5: Employment change from agriculture to non-agriculture in My Tan

\begin{tabular}{|l|c|c|}
\hline \multicolumn{1}{|c|}{ Targets } & No. & ratio \% \\
\hline The number of households with employment changes & 30 & 31.58 \\
\hline Number of employees and \% of total employees (30 households =78 workers) & 78 & 60.26 \\
\hline Impact & & \\
\hline Increase income (for these workers) & 39 & 82.98 \\
\hline Reduce income (for these workers) & 8 & 17.02 \\
\hline
\end{tabular}

Source: Author's survey data conducted in November 2018

- Developing industry, handicrafts and craft villages with job creation

In Nam Dinh province, there are $10 \mathrm{IZs}$ that have been approved by the Prime Minister to establish according to the Development Plan of IZs in Vietnam until 2015 and orientation to 2020. However, only 4 IZs (Hoa Xa, Bao Minh, My Trung, Rang Dong) have been, so far, built with a total ground area of $1,110.1$ ha, equal to $55.5 \%$ of the planned land. The total infrastructure investment capital is VND 6,290 billion; infrastructure investment capital reached nearly VND 1,400 billion, equaling to $2.3 \%$ of the total investment capital.

The development of industrial zones also contributes to the attraction of foreign investment capital for the locality. In December of 2005, only 8 foreign invested projects were licensed in Nam Dinh with a total registered capital of US\$ 70.71 million and the implemented capital of US\$ 61.63 million, by December 2018., there have been 102 licensed projects with a total registered capital of 3285.45 million US\$ and implemented capital of 351.93 million US\$.

Currently, 20 industrial clusters (ICs) have been established and put into operation, with a total planned land area of 419.17 hectares, implemented area is 334.71 hectares. In 2017, the Provincial People's Committee approved of adjusting and supplementing the master plan for IC development in the province until 2020, with a vision to 2025. Accordingly, in the period to 2020, in addition to 20 Ics in operation, 8 new ICs with a total area of 129.9 hectares will be established and 13 ICs with a total area of 234.2 hectares will be added to the plan; in the 20212025 period, 6 new ICs will be built with a total area of 128.1 hectares, 9 ICs with a total area of 250 hectares will be added to the plan and 23 ICs with a total area of 426.7 hectares will be expanded.

The industrialization process has brought about an increase in the number of enterprises doing business in the province, which is an important basis for creating jobs and speeding up the process of labor restructuring in Nam Dinh. By the end of 2005, Nam Dinh had 1,144 active businesses, in 2018 the number increased to 4,954 firms, of which nearly $40 \%$ of enterprises concentrated in Nam Dinh city, the remaining $60 \%$ were located in 9 districts. The number of employees in the province's businesses also increased from 117,068 in 2010 to 171,995 people in 2018 in which, labor in industrial and construction enterprises accounts for $82.19 \%$, in service businesses accounts for $16.38 \%$, the remaining $1.43 \%$ is the number of laborers working in agriculture, forestry and fishery enterprises.

However, the number of enterprises in the A-F-F sector only accounted for a small proportion of $1.58 \%$ of the total number of enterprises in 2018. This also shows the limitation of Nam Dinh in attracting businesses' investment in the agricultural sector which has originally been the strength of the province.

In parallel with the development of industrialization, rural employment opportunities in Nam Dinh have also rapidly increased along with the development of traditional craft villages and services. Currently, 70 craft villages, with more than 52,000 households and 310 production facilities have been recognized in the province, attracting more than 135,000 workers (accounting for $9 \%$ of the rural population of Nam Dinh).If the un-recognized trade villages areincluded because they are ineligible or have not yet applied for recognition, Nam Dinh has $129 \mathrm{craft}$ villages in 2018, with 310 manufacturing facilities. Many traditional trade villages of Nam Dinh have created their own product brand both at home and abroad, which can attract tourists, such as Tong Xa bronze casting village (Y Yen district), La Xuyen fine wood craft village (Y Yen district), craft villages (Xuan Truong district) and others.

Along with maintaining and developing existing traditional trade villages, Nam Dinh has also actively implemented new vocational training for rural workers such as industrial sewing. Some typical craft villages such as copper casting in the town of Lam, carpentry in Yen Ninh, craft in Xuan Tien and others have maintained, expanded production development and created permanent jobs for thousands of rural workers.

\subsection{Developing market economy and applying science and technology with job creation in rural areas}

Developing market economy and international economic integration is one of the most important factors that determine the quality of growth and employment creation in rural areas.

In cultivation, as a leading province in rice production in the RRD, Nam Dinh has established a number of commodity production areas with synchronous infrastructure for irrigation and transport such as high-yield rice areas, high-quality rice areas, specialty rice areas, specialized crop-growing areas and early-season rice areas + winter crops, building a large model field model. To strongly develop models of producing mushrooms, clean vegetables and safe vegetables (VietGAP) to meet the increasing demands of the market, Nam Dinh has also established a number of concentrated- commodity agricultural production areas associated with preservation, 
processing and consumption of diverse agricultural products such as peanut raw material, potatoes, vegetables in Y Yen, Vu Ban, Nam Truc; special rice areas in Hai Hau and Nghia Hung; flower, ornamental plants in Nam Truc, My Loc.

In animal husbandry, the province has focused on the sustainability-oriented development, ensuring disease safety and environmental sanitation, encouraging breeding of farms and farms concentrated far away from residential areas. The disease-free breeding areas associated with quality management along the value chain from production to consumption have been constructed.

In aquaculture the focus is on developing a variety of cultured species of high economic value (such as V1 carp, pink tilapia and snakehead fish in fresh water, also in salt and brackish water areas, apart from farming shrimp and clam, the farming sea crab, sea bass, grouper, cobia is also developed), along with the development of logistics services, processing and export of seafood.

The level of science and technology in agricultural and fishery production has gradually been improved towards the direction of using new varieties, applying biotechnology, advanced farming methods so as to increase productivity and quality of agricultural products and seafood.

In the context of international economic integration, major changes in domestic and international markets are creating many opportunities for farmers and agricultural businesses. The demand for high value-added processed products is increasing rapidly due to rising incomes, the speed of urbanization and commercialization, foreign investment and advanced technology. This development is opening up important market opportunities for agricultural, non-agricultural growth and rural employment and income as well. In those conditions, the key to creating competitiveness is that each business, each locality must determine for itself a sustainable competitive advantage. To create a sustainable competitive advantage, the key factor is to create a value added chain for products and services.

In recent years, Nam Dinh has begun to form a number of production linkage models along the value chain and initially gained good results.

There are also a number of other linkage models such as production linkage models based on the value chain of 4 cooperatives: Giao Ha, Giao Yen (Giao Thuy), Nam Thai, Nam Thanh (Dong Son) Nam Truc with the scale of 340 ha, the consumption of about 1,200 tons of Bac Thom (aromatic north) No. 7 for Northern Food Corporation. The model of linking production along the value chain in Yen Thanh and Yen Duong communes (Y Yen district), My Tan and My Tien communes (My Loc district) has signed with Ninh Binh Chilli Company to havelow-value crops replaced bychilli for export. The company has supported seeds, capital, deferred payment materials and underwritten all chili products for farmers and given an average income of VND 6-8 million an acre (Vietnamese sào) percrop.

Apart from the initial successes, in order to promote industrialization and modernization, it has been of great difficulties and obstacles for Nam Định to develop the market economy and commodity production in rural areas. The biggest difficulty lies in the unattainability of a solid export market; the weak construction and branding of products; the difficult access to medium and long-term capital to invest in production development; and most importantly, the value added chain for the products has not been created yet. The failure, itself, in the creation of value added chains for products has resulted in low prices, passive production, small quantity of exported products and consumers' limited awareness of product brands. This leads to the not-high income of the producers, which has not created the premise for sustainable development.

Another weakness in rural areas of Nam Dinh is that the agricultural enterprises are underdeveloped. Agriculture, forestry and fishery enterprises which play a huge role in creating linkages in the value chain only account for about $10 \%$ of the total number of enterprises in the province. Agricultural businesses have provided inputs for the agricultural sector and linked the agricultural sector with consumers through processing, transporting, marketing and distributing agricultural products. Therefore, dynamic and efficient agricultural business will promote agricultural growth and create linkages between enterprises and farmers and small farms, contributing to job creation for rural workers.

\section{Conclusion}

The process of industrialization and modernization has led to significant changes in the employment structure of rural workers in Nam Dinh province in recent years. There has been a positive shift in the employment structure from the agricultural sector to industry and services. This process has also positively changed the face of Nam Dinh rural areas, contributed to growth and accelerated economic restructuring, created diversification of trades in rural areas and increased the revenue sources of people from industry and service areas.

Initially, there has been a transformation of the market-economy-oriented agricultural production, formed new production cooperatives, linked with businesses and farmer households for production development and job creation of rural workers.

Besides, the quality improvement of the rural labor force is also paid attention to by local authorities. That's why, a number of farmer households have been able to promote their internal resources and existing conditions, 
apply scientific and technological advances to develop production, attract labor, get rich in the right way and increase job quality.

However, the current situation of job creation in Nam Dinh also shows inadequacies, first of all, the low economic growth rate due to the low production of goods. The effectiveness and competitiveness of the economy are not high, economic restructuring is slow, agricultural production is still in a small scale, scattered, based mainly on farmer households. Rural labor structure is slowly shifting and still concentrates mainly on the agricultural sector. Productivity, quality and competitiveness of agricultural products remain low. Research and transfer of science and technology into agricultural production are still slow... Employment, income and living standards of rural workers in Nam Dinh are low and unsustainable.

Attracting domestic and foreign investment capital into Nam Dinh, though progressing, is not strong enough to make "breakthroughs" in local economic development in order to "pull" rural laborers out of agricultural production. It is necessary to recognize the fact that the investment environment in the field of agriculture and rural areas still lacks attractiveness for domestic and foreign investors while agricultural and rural infrastructure, the qualifications and quality as well of the rural labor are poor. Besides, it is impossible not to mention the restrictions of the local administration apparatus, in which there is a phenomenon that a part of officials and public employees also show signs of harassment and troubles; the quality of administrative procedure reform and OSS mechanism implementation in some units is not high, affecting the investment environment and competitiveness index of the province. In fact, the process of industrialization and modernization has shown that localities such as Vinh Phuc, Bac Ninh, Quang Ninh... have got "breakthroughs" in development thanks to attracting investment capital and large enterprises from the outside. Because Nam Dinh, a province is endowed with strong advantage of agriculture, but bases on a small-scale agriculture, fragmented land and low efficiency, its accumulation will be low. Therefore, low economic growth rate, slow economic restructuring and employment structure are inevitable.

The development and economic restructuring of rural Nam Dinh have just relied on inherent resources, exploitation of the static advantages. For a long time, the model of development based on small-scale wet rice production is no longer appropriate and the policy of maintaining the fundamental position of rice production becomes a constraining factor of the rural economic restructuring to create jobs for workers. New thinking and policies are needed for the development of modern agriculture - sustainable development of commodity production with high productivity and quality, which will bring greater added value to agriculture and the quality of employment. That means, to create the quality jobs for farmers bases on the shift of not only product structure, but also the technological level of the product, or in other words, shifting the level of product quality according to technology to achieve high value added products. At the same time, it is necessary to create a market of giving jobs to rural labor on the basis of developing agricultural value chains along with the development of processing industry. Therefore, the application of high technology and the development of value chains is now an important tool to raise the added value of agriculture when other incentives for development such as land, labor, and part of the policy have been brought into full play.

It can be seen that Nam Dinh is facing great pressure on economic development and job creation for rural labor. The main "bottlenecks" lie in firstly, the disadvantage of the province's geo-economic position which makes the infrastructure fragmented, hindering Nam Dinh in connecting with outsiders to attract investment and large enterprises into rural areas in order to promote development. In the context of the development of an open economy, the lack of strong external links will be a major bottleneck in the province. Secondly, there are visionary issues and development policies on such areas as agriculture, industry and services of the local economy.

\section{References}

Begg, D. \& Fischer, S., \& Dornbusch, R. (2007), Economics, Statistical Publishing House.

Cling, J.P., Roubaud, F. (2009), Assessing the potential impact of the global crisis on the labour market and the informal sector in Vietnam.

Fine, B. (1998), Labour Market Theory: A constructive Reassessment, Routledge, London.

Ming, L., \& Jiang, S. (2008), Reform of the labor market, income inequality and economic growth in China. China and the World Economy, 16(6), 63-80.

Rhys, J. (2004), Why Has Employment Not Grown More Quickly in Vietnam, Journal of the Asia Pacific Economy, 9(2), 191-208.

Rhys, J. (2006), Globalization, FDI and employment in Viet Nam", Transnational Corporations, 15(1), 115-142.

Todaro, M.P. (1976), Internal Migration in Developing Countries: A Review of Theory, Evidence, Methodology and Research Priorities," International Labour Office, Geneva. 26.

Todaro, M.P. and Harris, J. (1970), Migration Unemployment and Development: A Two Sectors Analysis, American. Economic. Review, 60 (1):126-42.)

Todaro, M.P. and Harris, J. (1976), Urban Job Expansion, Induced Migration and Rising Unemployment: a Formulation and Simplified Empirical Test for LDCs, Journal of Development Economics, 3(3), 211-22.

Turnham, D. (1971), The Employment Problem in Less Developed Countries, Development Centre of the Organization for Economic Co-operation and Development. 